\title{
EBF factors drive expression of multiple classes of target genes governing neuronal development
}

\author{
Yangsook S Green and Monica L Vetter
}

\begin{abstract}
Background: Early B cell factor (EBF) family members are transcription factors known to have important roles in several aspects of vertebrate neurogenesis, including commitment, migration and differentiation. Knowledge of how EBF family members contribute to neurogenesis is limited by a lack of detailed understanding of genes that are transcriptionally regulated by these factors.

Results: We performed a microarray screen in Xenopus animal caps to search for targets of EBF transcriptional activity, and identified candidate targets with multiple roles, including transcription factors of several classes. We determined that, among the most upregulated candidate genes with expected neuronal functions, most require EBF activity for some or all of their expression, and most have overlapping expression with ebf genes. We also found that the candidate target genes that had the most strongly overlapping expression patterns with ebf genes were predicted to be direct transcriptional targets of EBF transcriptional activity.

Conclusions: The identification of candidate targets that are transcription factor genes, including $n s c l-1$, em $x 1$ and am/1, improves our understanding of how EBF proteins participate in the hierarchy of transcription control during neuronal development, and suggests novel mechanisms by which EBF activity promotes migration and differentiation. Other candidate targets, including pcdh8 and kcnk5, expand our knowledge of the types of terminal differentiated neuronal functions that EBF proteins regulate.
\end{abstract}

\section{Background}

Throughout animal development, many processes must occur coordinately, including patterning, commitment, differentiation and migration of progenitor cells. In the nervous system in particular, these processes are exceedingly complex and depend on the coordinated expression of many sets of genes. A detailed understanding of gene regulation, including knowledge of the hierarchy of transcriptional activity and the types of genes that different transcription factors target, is therefore a critical foundation for understanding nervous system development. One group of transcription factors expressed strongly in the developing nervous system is the early $\mathrm{B}$ cell factor (EBF; also called Collier/Olf/Ebf (COE), and Olf/Ebf (O/E)) family of zinc finger helix-loop-helix proteins.

The EBF family includes EBF1, 2, 3 and O/E-4 in mammals [1-6], with EBF2 and EBF3 being the known family members in Xenopus $[7,8]$, and ZCOE2 a family member

\footnotetext{
* Correspondence: monica.vetter@neuro.utah.edu

Department of Neurobiology and Anatomy, University of Utah School of Medicine, Salt Lake City, UT 84132, USA
}

in zebrafish [9]. Invertebrate members of this family include Collier in Drosophila, and UNC-3 in Caenorhabditis elegans $[10,11]$. EBF family proteins contain a DNA binding domain (a zinc finger coordination motif), which can also participate in dimerization and transactivation, an atypical helix-loop-helix domain, which is critical for formation of homo- and heterodimers, and a carboxyterminal domain, which is important for transactivation $[2,4,12]$.

EBF proteins influence multiple processes during development of multiple lineages, including neurons (reviewed in $[13,14])$. One of their functions is a role in stabilizing neuronal cell commitment. For example, Dubois et al. [7] showed that EBF2 can affect neuronal progenitor cell commitment in early Xenopus embryos by reinforcing the expression of the proneural basic helix-loop-helix (bHLH) transcription factor NGNR-1, and by maintaining the expression of delta1. In addition, in developing chick spinal cord, electroporated mouse Ebf1 drives expression of Ngn1 and Ngn2 [15].

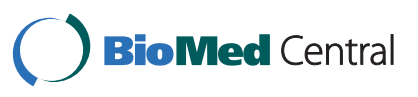

(C) 2011 Green and Vetter; licensee BioMed Central Ltd. This is an Open Access article distributed under the terms of the Creative Commons Attribution License (http://creativecommons.org/licenses/by/2.0), which permits unrestricted use, distribution, and reproduction in any medium, provided the original work is properly cited. 
EBF proteins also have critical roles in neuronal cell differentiation. For example, overexpression of ebf 2 and ebf3 leads to ectopic expression of neuronal-specific markers like $n$-tubulin and $n f-m$ in Xenopus embryos $[7,8]$, suggesting that EBF2 and EBF3 may drive specific aspects of the neuronal differentiation program. Consistent with this, in Ebf1 null mouse striatum, early neuronal cells show abnormal expression of several genes, indicating disruption of the process of differentiation [16]. EBF proteins have also been shown to regulate aspects of cell differentiation in both Drosophila and C. elegans ventral nerve cord $[17,18]$, as well as in early chick spinal cord, where electroporated mouse Ebf1 promotes expression of numerous neuronal markers [15].

EBF proteins have been shown to regulate neurite formation and axon guidance, including thalamocortical fibers in the mouse lateral ganglionic eminence $[16,19]$, olfactory axons projecting to the mouse olfactory bulb [20], as well as motor neurons in C. elegans [11]. EBF proteins also are critical for neuronal cell migration. For example, EBF factors regulate the migration of gonadotropin releasing hormone ( $\mathrm{GnRH}-1)$-synthesizing neurons from the olfactory epithelium to the hypothalamus [21], the migration of Purkinje neurons from the anterior cortical transitory zone to beneath the external granular layer in cerebellar cortex [22], and the migration of facial branchiomotor neurons in the hindbrain [23]. Furthermore, when Ebf1 is misexpressed in chick spinal cord, neuroepithelial progenitors migrate toward the mantle layer faster than normal, and the expression levels of $N F$ and $R$ cadherin are upregulated [15].

Ebf genes are strongly expressed in differentiating central and peripheral neurons throughout development $[1,7,8,24]$, and clearly govern diverse aspects of neuronal development. However, it is not fully understood how these functions are executed since there has not previously been a systematic analysis of EBF transcriptional targets involved in neuronal development. The goals of this study were as follows. First, we performed a microarray analysis to identify candidate targets of EBF3 activity in the developing Xenopus nervous system. Second, we analyzed the expression of the candidate targets, to compare their expression with the ebf genes and to gain an understanding of where in the embryo they may function. Third, we performed gain- and loss-of-function studies of EBF2 and EBF3 in Xenopus embryos to analyze in vivo the dependence of the discovered candidate targets on EBF activity, and to confirm the microarray results in vivo. Finally, we assessed which candidate target genes are likely to be direct targets of EBF3, and which are indirect targets, to better understand the hierarchy of transcriptional control by EBF proteins. Many genes previously demonstrated to be required for neuronal development are strongly upregulated by EBF, but were not previously known to be targets of EBF transcriptional activity. These targets include transcription factors, cell structural proteins, an ion channel protein, and a gene involved in transforming growth factor (TGF)-beta signaling. The variety of targets found expands our knowledge of the kinds of processes EBF proteins regulate, and reinforces the idea that EBF proteins can influence many aspects of neuronal development because they direct expression of several different functional classes of genes. The discovered candidate targets open a new window to understanding the broader scope of EBF functions.

\section{Materials and methods}

\section{Generation of hormone-inducible constructs}

To generate hormone-inducible constructs, a hormonebinding domain of the human glucocorticoid receptor (hGR) was fused to the coding region of Xenopus ebf3 (or ebf2), with a myc tag epitope between hGR and the coding region (Additional file 1A) [25,26]. The ebf3 coding region was obtained by excision from pBS-Xebf3 [8] with the restriction enzyme DraI, which produces a DNA fragment with blunt ends. The hormone-binding domain was obtained from the pCS2+hGR-MT vector (hGR with myc tag) by cutting with XbaI and treatment with Klenow (Promega, Madison, WI, USA) to generate blunt ends followed by dephosphorylation of the 3' ends with CIP (New England Biolabs, Ipswich, MA, USA). The excised ebf3 was then subcloned into the $\mathrm{pCS} 2+\mathrm{hGR}-\mathrm{MT}$ vector. To generate hGR-XEBF2 construct, pBS-Xebf2 [8] was used as a template and the following primers containing XhoI and XbaI sites were used to amplify ebf2: 5'-GGCCCTCGAGATGGATCCAATCCA-3' and 5'-GGCCTCTAGATTCACATGGGCACC-3' (residues in italics are XhoI and XbaI sites, respectively; bold sequences are the ebf2 sequence). The amplified products were digested with XhoI and XbaI and subcloned into the pCS2+hGR-MT vector. Following sequence verification, the in vivo expression of these fusion proteins was verified by injecting capped mRNAs into Xenopus embryos at the one-cell stage and then performing western blotting with lysates of gastrula stage embryos with 9E10 antibody (Santa Cruz Biotechnology, Santa Cruz, CA, USA), which recognizes the myc epitope (data not shown).

\section{Microinjection of RNA and morpholinos}

The following constructs were used as DNA templates to make capped mRNA: pCS2+Noggin [27], pCS2+hGR [28], pCS2+hGR-MT-Xebf2, pCS2+hGR-MT-Xebf3, pCS2+MT-DN-Xebf, and pCS $2+n \beta$ gal [29]. Capped mRNA was generated in vitro using the Message mMachine kit (Ambion, Austin, TX, USA). Antisense morpholino oligonucleotides (MO) were designed by Gene Tools (Philomath, OR, USA), and directed against a region at or near the translational start site of $e b f 2$ 
(5'-GCGCTTTGTCTCTCAAGGCAGTTCC-3') and ebf3 (5'-GTATATTTTCCTGAATCCCAAACAT-3').

For microarray experiments, 1 ng of hGR-XEBF3 mRNA and $0.2 \mathrm{ng}$ Noggin mRNA were co-injected into Xenopus embryos at the one-cell stage. Alternatively, 0.4 ng hGR mRNA and 0.2 ng Noggin mRNA were co-injected in control embryos. At stage 9, animal caps were dissected from the embryo, using either a Gastromaster or a hypodermic needle tip. Animal caps were treated with $30 \mu \mathrm{M}$ dexamethasone (DEX) in 1× Marc's modified Ringer solution (MMR) for 4.5 hours before harvesting of total RNA (Additional file 1B).

For all other microinjections, a volume of $4 \mathrm{nl}$ or $5 \mathrm{nl}$ containing capped mRNA or MOs was injected into one blastomere of two-cell stage embryos in the following amounts: hGR (0.5 ng), hGR-XEBF2 (0.5 ng for overexpression, $0.1 \mathrm{ng}$ for the MO rescue), hGR-XEBF3 (0.5 ng), DN-XEBF (2 ng), MyoD-hGR (0.5 ng), n $\beta$ gal (30 pg), EBF2 MO (15 ng), EBF3 MO (15 ng) and standard control $\mathrm{MO}$ (30 ng). In the MO experiments, both EBF2 MO and EBF3 MO were co-injected. For all injections $n \beta$ gal capped mRNA was co-injected as a tracer. Embryos were grown until neurula or tail bud stages [30]. hGR-XEBF2, hGRXEBF3 and MyoD-hGR injected embryos were treated with $30 \mu \mathrm{M}$ DEX from the gastrula stage (stage 11/11.5) to the neurula stage (stage 14/15). Embryos were then fixed with $4 \%$ paraformaldehyde in phosphate-buffered saline for 30 minutes. After washing embryos three times with phosphate-buffered saline, X-gal staining was performed as described [31], followed by post-fixation in $4 \%$ paraformaldehyde for 1 hour at room temperature or overnight at $4^{\circ} \mathrm{C}$.

\section{Microarray analysis}

Total RNA was isolated from animal caps with the RNeasy mini kit (Qiagen, Germantown, MD, USA). This RNA was used to perform two-color microarray analysis on the Xenopus Agilent microarray by the University of Utah Microarray core facility. Fluorescently labeled cRNA, containing either cyanine 3-CTP or cyanine 5-CTP, was generated using the Agilent Two-Color Quick Amp Labeling kit (catalog number 5190-0444). Next, microarray hybridizations were performed using Agilent surehyb hybridization chambers. Slides were then scanned in an Agilent Technologies G2505B microarray scanner at $5 \mu \mathrm{m}$ resolution. Finally, TIF files were generated from the scanned microarray image, and loaded into Agilent Feature Extraction Software version 9.5.1. LOWESS-normalized data from the Feature Extraction software was filtered to remove control features and features flagged as 'nonuniform'. The LOWESS-normalized intensity values were loaded into Genesifter software (Geospiza, Seattle, WA, USA) for analysis. A $t$-test was applied to data from four biological replicate experiments. $P$-values from the $t$-test were adjusted for multiple testing using the Benjamini and Hochberg method. Genes were selected that showed at least two-fold differential expression and had adjusted $P$-values $<0.05$.

\section{In situ hybridization}

The following constructs were used to generate antisense RNA probes: pBS-Xebf2 [8], pBS-Xebf3 [8], pBS-Sox2 [32], PCDH8 (IMAGE ID 6955713, ATCC), Peripherin (IMAGE ID 4959167, ATCC), GREB1 (IMAGE ID 5569934, ATCC), pBS-XNF-M [8], KCNK5 (IMAGE ID 6863628, ATCC), NSCL-1 (IMAGE ID 5514274, ATCC), pBS-XNeuroD [33], AML1 (IMAGE ID 4963637, ATCC), Activin beta B (IMAGE ID 5440215, ATCC), EMX1 (IMAGE ID 6957219, ATCC). Antisense RNA probe was generated in vitro using SP6, T7 or T3 RNA polymerase (Ambion) and labeled with digoxigenin-11-UTP (Roche, Indianapolis, IN, USA). Whole mount in situ hybridization was performed on the fixed and X-gal stained embryos as described [34,35].

\section{Real-time quantitative PCR}

For real-time quantitative PCR (RT-QPCR) experiments, $1 \mathrm{ng}$ hGR-XEBF3 mRNA and 0.2 ng Noggin mRNA were co-injected into Xenopus cells at the one-cell stage and animal caps were isolated at stage 9 . The animal caps were divided into four groups. The control group received no treatment (-C-D). The second group was treated with 30 $\mu \mathrm{M}$ DEX alone for 3 hours $(-\mathrm{C}+\mathrm{D})$, and the third group was treated with $5 \mu \mathrm{g} / \mathrm{ml}$ cycloheximide (CHX) alone for 3.5 hours $(+C-D)$. Finally, the fourth group was treated with $5 \mu \mathrm{g} / \mathrm{ml} \mathrm{CHX}$ for 30 minutes and then $30 \mu \mathrm{M}$ DEX was added for 3 hours $(+C+D)$. Total RNA was purified from animal caps with Trizol (Invitrogen) and then genomic DNAs were removed with the RNeasy mini kit (Qiagen).

To make cDNA from the isolated total RNA from animal caps, the SuperScript III reverse transcriptase (Invitrogen) was used according to the manufacturer's instructions, and then QPCR was performed using Power SYBR Green PCR Master Mix (Applied Biosystems, Carlsbad, CA, USA) on a 7900HT Real Time PCR System (Applied Biosystems). Alternatively, the Superscript III Platinum two step RT-QPCR kit and SYBR Green (Invitrogen) were used to make cDNA and to generate the PCR solution, and QPCR was performed on the same 7900HT Real Time PCR system. MacVector Software was used to design the gene-specific primers (Additional file 2). The relative gene expression level was determined by normalizing the threshold cycle $(\mathrm{Ct})$ of each gene to the $\mathrm{Ct}$ of histone $\mathrm{H} 4$. One $\mathrm{Ct}$ difference indicates a twofold difference in the initial cDNA template amount. Finally, expression levels were normalized by setting the expression level in the condition of $-\mathrm{C}+\mathrm{D}$ to 100 . 


\section{Results}

Identification of candidate targets of EBF3 in animal caps

To identify transcriptional targets of EBF3, we performed a microarray screen comparing the transcripts expressed in Xenopus animal cap ectoderm with and without active Xenopus EBF3 protein. To control EBF3 activity, we generated a hormone-inducible fusion protein (hGR-XEBF3) that can be regulated by the hormone DEX (Additional file 1A) [26]. We verified that the fusion protein hGRXEBF3 replicates EBF3 activity in vivo by demonstrating that hGR-XEBF3 activated by DEX treatment can induce ectopic expression of $n$-tubulin (data not shown) and neurofilament-m $(n f-m)$ (Figure $1 \mathrm{H})$, similar to unmodified EBF3 [8]. For all microarrays, we injected mRNA encoding hGR-XEBF3 into one-cell stage embryos, collected animal caps at the blastula stage, and treated with DEX for 4.5 hours (to activate hGR-XEBF3 and induce target gene expression), followed by isolation of total RNA (Additional file 1B). Control animal caps without active hGR-XEBF3 were generated in the same way, but without the addition of DEX.

EBF proteins are involved in the development of B cells, adipocytes, and muscle cells, as well as of neurons (reviewed in $[13,14,36]$ ), and the activities of EBF are tissue specific [37]. Since we were interested primarily in neuronal-specific targets of EBF activity, we co-injected embryos with Noggin mRNA to neuralize the animal caps [27]. Agilent Xenopus microarrays were used to compare target gene expression levels in DEX-treated animal caps to those in control DEX-untreated animal caps in four independent experiments. To exclude genes that had their expression levels affected by the hormone DEX alone, we performed a separate, control microarray analysis using animal caps treated with DEX expressing control hGR versus untreated animal caps expressing hGR-XEBF3 (Additional file $1 \mathrm{~B}$ ). After removal of the small number of genes that were affected by DEX itself, we found 602 genes that were upregulated more than two-fold, and 504 genes that were downregulated more than two-fold by EBF3 activity (Additional file 3; Gene Expression Omnibus (GEO) accession [GEO:GSE25734]). We found 242 genes upregulated more than five-fold, and 115 genes downregulated more than five-fold.

In cases of incomplete annotation for the Xenopus microarray, we used NCBI UniGene or BLAST to identify homologs in other species and determine likely gene identity. The list of candidate targets includes genes with known functions in neurons, as well as genes with established roles in other tissue types, including muscle. Since EBF proteins have not previously been implicated in vertebrate muscle development, an analysis of EBF3 targets with functions in muscle tissue are described in a separate study (YS Green and ML Vetter, submitted). An indication of the integrity of our screen was the strong upregulation of $n f-m$, a known EBF3 target gene [8] (Table 1). As a whole, the results of this array provide an expansive data set for future study of EBF3 activity in Xenopus.

\section{Classes of candidate target genes with predicted neuronal function}

The list of targets with predicted neuronal function was very promising, so for further analysis, we selected from the microarray results 14 genes that were more than 10 fold upregulated and that we predicted to be involved in neuronal development, based on expression patterns and functions known from the published literature, as well as on our own observations with whole mount in situ hybridization (WM-ISH; discussed below). Although the number of downregulated genes in our array results is comparable to the number upregulated, we focused on upregulated genes for the remaining analysis to identify potential mediators of EBF function in the nervous system. The selected EBF3 candidate target genes were classified based on their known or predicted functions, and these are summarized in Table 1. To confirm the microarray results for these genes, reverse transcriptase PCR (RTPCR) was performed using independent animal caps from those used in the microarray experiments. For each tested gene, these RT-PCR results showed significant upregulation of gene expression by activated hGR-XEBF3, matching the results found with the microarray analysis (data not shown). As described in detail later, for a subset of the genes we performed RT-QPCR using independent samples, and also found upregulation of gene expression (Table 1). To determine whether neuralization of the animal caps was required for EBF regulation of candidate target genes, we performed an additional microarray experiment using the same conditions, but without Noggin mRNA co-injection (Additional file 4; GEO accession [GEO:GSE27084]). We found that all 14 genes were still upregulated by hGR-XEBF3 in the presence of DEX, suggesting that they can be activated by EBF activity in both neuralized and non-neuralized ectoderm.

After classification, we found that a large number of the selected candidate EBF targets are transcription factors for example, NR2F2 (nuclear receptor subfamily 2, group F, member 2, also called COUP-TFII) [38], HOXD10 (homeobox D10, also called HOX4D) [39], NSCL-1 (neuronal stem cell leukemia, also called XHEN1 and NHLH1) [40], NeuroD [33], EN-2 (engrailed 2) [41], AML1 (acute myeloid leukemia, also called RUNX1) [42,43], and EMX1 [44]. The fact that we find many transcription factors strongly upregulated by EBF proteins suggests that there are multiple levels of transcriptional control that involve the activity of EBF proteins. For the most part, the remainder of the strongly upregulated candidate targets that we 


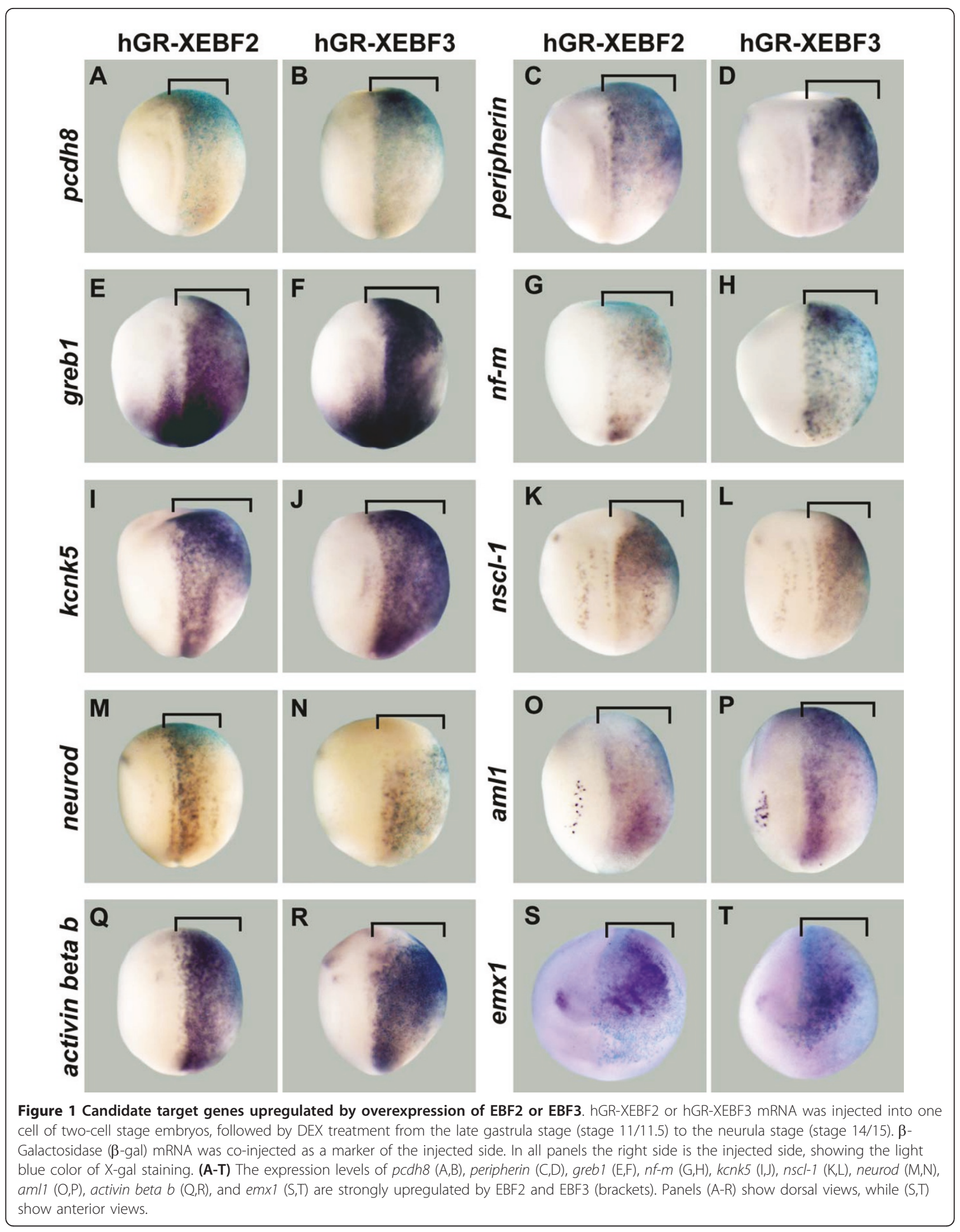


Table 1 Candidate targets of EBF activity

\begin{tabular}{|c|c|c|c|c|}
\hline Gene name & Function & $\begin{array}{c}\mathrm{FC}^{1} \\
\text { (microarray) }\end{array}$ & $\begin{array}{c}\mathrm{FC}^{2} \\
\text { (RT-QPCR) }\end{array}$ & GenBank \\
\hline$\overline{p c d h 8}$ & Transmembrane protein & 66 & $93^{\mathrm{a}}$ & BC074360 \\
\hline$n r 2 f 2$ & Nuclear receptor TF & 47 & ND & BC078057 \\
\hline$w n t 3 a$ & Wnt signaling ligand & 45 & ND & L07538 \\
\hline peripherin & Type III intermediate filament & 37 & $32^{\mathrm{a}}$ & BC056020 \\
\hline greb1 & Estrogen-regulated gene & 32 & $21^{\mathrm{b}}$ & BC043838 \\
\hline hoxd10 & Homeodomain TF & 31 & ND & BC061944 \\
\hline$n f-m$ & Type IV intermediate filament & 28 & $29^{b}$ & BC078128 \\
\hline$k c n k 5$ & K+ ion channel & 27 & $6^{\mathrm{b}}$ & BC084931 \\
\hline nscl-1 & bHLH TF & 26 & $7^{b}$ & BC084434 \\
\hline neurod & bHLH TF & 26 & $164^{\mathrm{b}}$ & BC072996 \\
\hline en-2 & Homeodomain TF & 24 & ND & X62974 \\
\hline$a m / 1$ & Runt-related TF & 22 & $24^{\mathrm{a}}$ & BC057739 \\
\hline activin beta $b$ & TGF-beta superfamily member & 21 & $154^{\mathrm{b}}$ & S61773 \\
\hline$e m \times 1$ & Homeodomain TF & 16 & $15^{\mathrm{b}}$ & BC077629 \\
\hline
\end{tabular}

The genes chosen for analysis are shown with their known functional roles. FC $^{1}$ refers to the average fold change in expression by microarray analysis after DEX treatment for 4.5 hours compared to control, in four replicate experiments. $\mathrm{FC}^{2}$ refers to the fold change in expression after DEX treatment for 3 hours compared

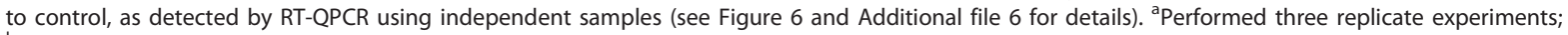

${ }^{b}$ performed once. FC, fold change; ND, not determined; TF, transcription factor.

chose are involved in cell structure and neuronal function, including PCDH8 (protocadherin 8) [45], WNT3a [46], Peripherin (also called XIF3) [47] and NF-M (Neurofilament-M) [48], KCNK5 (potassium channel subfamily K member 5, also called TASK2) [49], and Activin beta B (also called INHBB) [50], reinforcing the idea that EBF proteins are involved in neuronal differentiation during development, as well as performing various functions in mature neurons.

\section{EBF2 and EBF3 are sufficient for the expression of candidate neuronal targets in vivo}

We previously showed that the protein sequences of Xenopus EBF2 and EBF3, as well as their functions in neuronal development in Xenopus, are very similar [8]. For these reasons, we included both EBF2 and EBF3 in the experiments that follow. In order to both confirm the microarray data and to determine if EBF2 and EBF3 are sufficient for the expression of the candidate target genes in vivo, we examined the expression levels of candidates after overexpression of hGR-XEBF2 and hGR-XEBF3. Overexpression was achieved by injection of mRNA for hGR-XEBF2 or hGR-XEBF3 into one cell of two-cell stage embryos, followed by treatment of the embryos with DEX from the gastrula stage (stage $11 / 11.5$ ) to the neurula stage (stage 14/15). The expression level of candidate target genes was then examined by WM-ISH. We found that 10 of the 14 candidate target genes were upregulated by overexpression of EBF2 and EBF3 (Figure 1). These were pcdh 8 (20/23 embryos by EBF2, 27/28 embryos by EBF3), peripherin $(15 / 15,35 / 35)$, greb1 (genes regulated by estrogen in breast cancer; 12/12, 10/10), nf-m (15/15, 35/38), kcnk5
(11/11, 39/40), nscl-1 (9/9, 33/40), neurod (20/21, 39/39), aml1 (12/12, 11/11), activin beta $b(11 / 11,37 / 40)$, and emx1 $(11 / 13,28 / 32)$ (Figure 1). However, four genes were not consistently upregulated by EBF3. The expression of en-2 (10/19) and hoxd10 (30/44) was downregulated, while the expression of $n r 2 f 2$ was upregulated (19/73) in some embryos but downregulated (30/73) in others, and the expression of wnt3a (24/24) was not changed by EBF3 (data not shown). We therefore believe that these four genes are unlikely to be in vivo targets of EBF activity at this stage of early nervous system development, and we have excluded them from the experiments that follow. The fact that the expression levels of 10 genes among 14 candidates are upregulated by overexpression of EBF2 and EBF3 in the intact embryo supports the microarray data, and further shows that EBF2 and EBF3 activity are sufficient to drive expression of these candidate genes in vivo.

\section{EBF2 and EBF3 are required for the expression of candidate targets in vivo}

To determine if the expression of our identified candidate target genes is dependent on EBF2 and EBF3 in vivo, we examined the expression levels of candidate targets after knockdown of EBF2 and EBF3 expression using translation blocking antisense MOs. EBF2 MO and EBF3 MO were co-injected into one cell of two-cell stage embryos and the expression levels of endogenous candidate target genes were examined at the neurula stage (stage $15 / 16$ ) or tailbud stage (stages 25 to 28), when expression of candidate target genes is apparent (Figures 2 and 3). We first confirmed that expression of the neural plate marker sox 2 was not changed (10/10 embryos; Figure 2B), indicating 

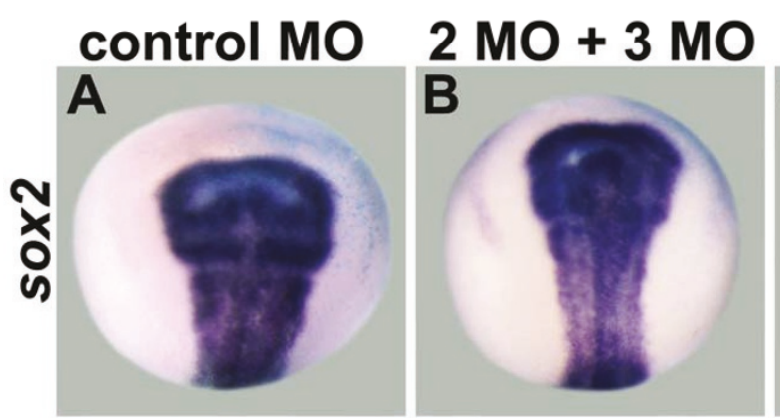

\section{DN-XEBF}
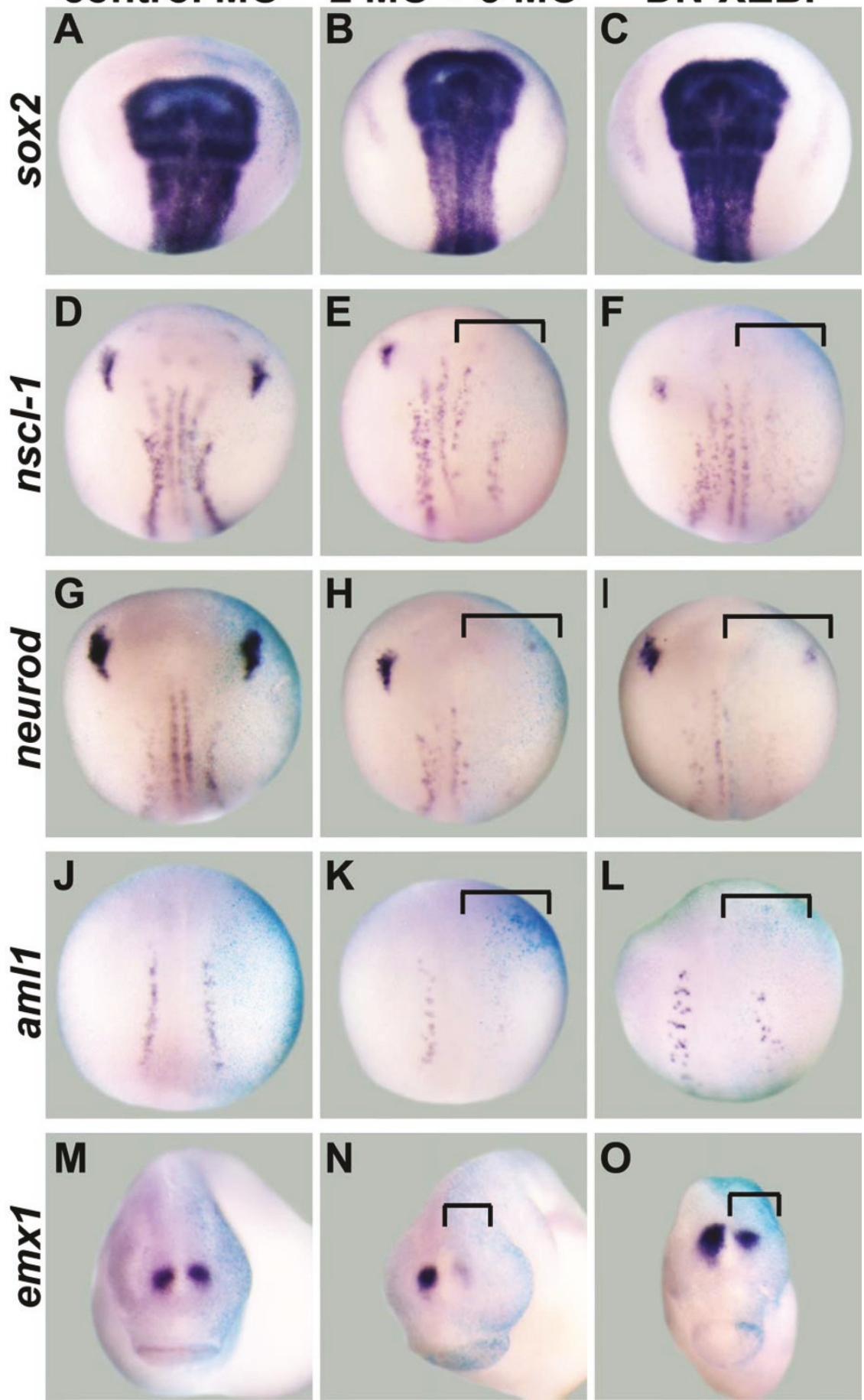

Figure 2 Downregulation of transcription factor candidate target genes after knockdown of EBF2 and EBF3. One cell of two-cell stage embryos was injected with either control MO, both EBF2 MO and EBF3 MO (2MO + 3MO), or dominant negative Xenopus EBF3 (DN-XEBF) mRNA. $\beta$-Galactosidase ( $\beta$-gal) mRNA was co-injected as a marker of the injected side. In all panels the right side is the injected side, showing the light blue color of X-gal staining. (A-C) The expression of sox2 was not changed in all three conditions. (D-O) The expression of nscl-1 (E,F), neurod $(\mathrm{H}, \mathrm{I}), \operatorname{am} / 1(\mathrm{~K}, \mathrm{~L})$, and emx1 $(\mathrm{N}, \mathrm{O})$ is downregulated by EBF2 $\mathrm{MO}$ and EBF3 MO, and by DN-XEBF (brackets), while control MO does not change their expression levels $(D, G, J, M)$. Panels (A-L) show dorsal views of neurula stage embryos (stage 15/16), and (M-O) are anterior views of tail bud stage embryos (stages 25 to 28). 

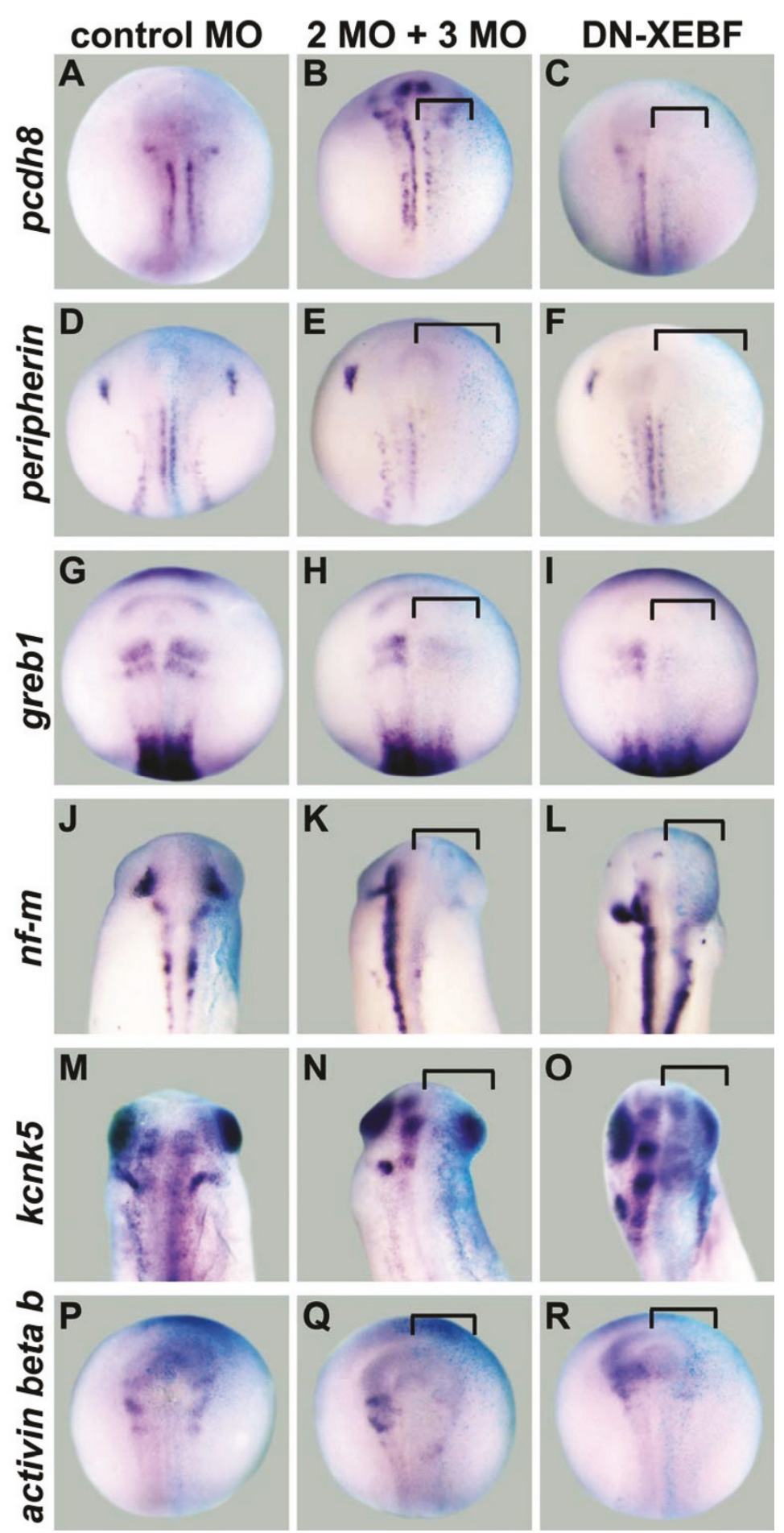

Figure 3 Downregulation of non-transcription factor candidate target genes after knockdown of EBF2 and EBF3. One cell of two-cell stage embryos was injected with either control MO, both EBF2 MO and EBF3 $\mathrm{MO}$ (2MO + 3MO), or dominant negative Xenopus EBF3 (DN-XEBF) mRNA. $\beta$-Galactosidase ( $\beta$-gal) mRNA was co-injected as a marker of the injected side. In all panels the right side is the injected side, showing the light blue color of $\mathrm{X}$-gal staining. (A-R) The expression of pcdh8 (B,C), peripherin $(\mathrm{E}, \mathrm{F})$, greb1 $(\mathrm{H}, \mathrm{I}), n f-m(\mathrm{~K}, \mathrm{~L}), \mathrm{kcnk5}(\mathrm{N}, \mathrm{O})$, and activin beta b $(\mathrm{Q}$, $\mathrm{R}$ ) is downregulated by EBF2 $\mathrm{MO}$ and EBF3 MO, and by DN-XEBF (brackets), while control MO does not change their expression levels ( $\mathrm{A}, \mathrm{D}, \mathrm{G}, \mathrm{J}, \mathrm{M}$, P). Panels (A-I) and (P-R) are neurula stage embryos (stage 15/16), and (J-O) are tail bud stage embryos (stages 25 to 28). All panels show dorsal views. 
that knockdown of EBF2 and EBF3 did not affect early global neuronal development in the early embryos. After co-injection of EBF2 MO and EBF3 MO, the expression of nscl-1 (10/11), neurod (13/15), aml1 (7/12), emx1 (12/15), pcdh8 (12/13), peripherin (11/11), greb1 (11/12), nf-m (14/16), kcnk5 (10/15) and activin beta $b(5 / 10)$ were downregulated (Figures 2 and 3). Control MO did not change the expression levels of these genes (Figures 2 and 3 ). The expression of peripherin was partially rescued by co-injecting EBF2 MO and EBF3 MO together with mRNA for hGR-XEBF2, which does not have overlapping sequence with the MOs, and then treating with DEX from the gastrula stage (stage 11.5) to the neurula stage (stage 15/16) (Additional file 5). This control demonstrates that the EBF2 MO and EBF3 MO specifically block EBF activity.

To confirm the MO results, we generated a dominant negative Xenopus EBF3 construct (DN-XEBF). This DNXEBF (amino acids 349 to 598) lacks the DNA binding domain in the amino-terminal region, but it has an intact dimerization domain $[4,7,12]$. Since EBF1, 2, and 3 can form homodimers or heterodimers in vitro $[2,4,12]$, this DN-XEBF is predicted to block the function of both EBF2 and EBF3 by forming non-functional dimers. Similar to our MO data, injection of mRNA encoding DN-XEBF led to downregulation of the expression of $n s c l-1$ (5/13 embryos), neurod (12/18), aml1 (6/14), emx1 (7/15), pcdh8 (8/18), peripherin (8/13), greb1 (8/14), nf-m (10/19), kcnk5 (7/19) and activin beta $b(8 / 17)$ (Figures 2 and 3) while sox2 expression was not changed by DN-XEBF at the neurula stage $(13 / 14)$ (Figure 2C). However, the level of downregulation of candidate target genes was weaker than that obtained by $\mathrm{MO}$ injection, perhaps because some endogenous EBF protein is able to form normal dimers even in the presence of DN-XEBF. In addition, a majority of embryos became bent toward the injected side at the tailbud stage because this side was smaller than the uninjected side (data not shown), suggesting changes in the development of other tissues. Taken together, these function-blocking experiments with MOs and DN-XEBF suggest that EBF2 and EBF3 are required for the expression of our neuronal candidate targets in vivo.

\section{Comparison of the expression patterns of EBF2, EBF3 and their candidate targets in the Xenopus nervous system}

To determine if the functional relationships we identified above might be indicative of in vivo genetic relationships between $e b f$ genes and candidate targets, and to determine if the candidate targets have expression patterns consistent with a role in neuronal development, we compared the expression domains of ebf2 and ebf 3 with those of candidate target genes by WM-ISH at four different stages in early Xenopus embryos: stage 12.5 (data not shown), 15, 23 and 28 (Figures 4 and 5). We chose these stages because the expression of $e b f 2$ is visible from stage 12.5 , the expression of ebf 3 is clearly visible at stage 15 , and their expression continues beyond stage $28[7,8]$. $e b f 2$ and $e b f 3$ are expressed in very similar neuronal tissues (Figure 4A-F). At stage 15, both are expressed in the three stripes (medial, intermediate, and lateral) of primary neurons in the neural plate and trigeminal placodes. At stage 23, both are expressed in the trigeminal placodes, the olfactory placodes, spinal cord, and neural crest derivatives, including branchial arches. By stage 28 , their expression expands to encompass much of the developing brain.

First, we compared the expression patterns of $e b f$ genes and the candidate targets that are known transcription factors since a number of candidate target genes fell into this category (Figure 4). The expression patterns of both bHLH transcription factors, nscl-1 (Figure 4G-I) [40] and neurod (Figure 4J-L) [33], overlap strongly with those of ebf2 and ebf3 in the three stripes of primary neurons, trigeminal placodes, olfactory placodes and spinal cord. In Xenopus embryos, the neuronal expression of aml1 (Figure 4M-O) [42,43] is limited to sensory neurons, including the lateral stripe at stage 15 , sensory neurons in the spinal cord at stage 23 , and olfactory placode at stage 28 , and this expression pattern overlaps with the expression of $e b f 2$ and $e b f 3$. The expression of $e m x 1$ (Figure 4P-R) [44] in the dorsal forebrain region at stages 23 and 28 overlaps with the expression of ebf2 and ebf3.

Second, we compared the expression patterns of ebf genes and the candidate targets that do not have transcriptional activity, and that were predicted to play a role in cell structure and neuronal function (Figure 5). The expression of $p c d h 8$ (Figure 5A-C) does partially overlap with that of ebf 2 and $e b f 3$ in two stripes of primary neurons, spinal cord, midbrain, and hindbrain. The neuronal intermediate filament genes peripherin (Figure 5D-F) [51] and $n f-m$ (Figure 5J,K) [52] show strongly overlapping expression patterns with ebf 2 and $e b f 3$ in the three stripes of primary neurons, trigeminal placodes, olfactory placodes and spinal cord from the earliest stages in which they are expressed. The expression patterns of greb1 (Figure 5G-I), kcnk5 (Figure 5L-N) and activin beta $b$ (Figure 5O-Q) [50] do not overlap with those of ebf2 and ebf 3 at stage 15 , but partially overlap in some domains in the brain or the spinal cord at stages 23 or 28 .

In summary, the candidate EBF target genes show complex patterns of expression during nervous system development with different degrees of overlap with the EBF factors. For example, some were highly overlapping, $n s c l-$ 1 , neurod, aml1, peripherin, and $n f-m$, while others showed more limited overlap, such as $e m \times 1, p c d h 8$, greb1, kcnk5, and activin beta b. The genes pcdh8, greb1, 


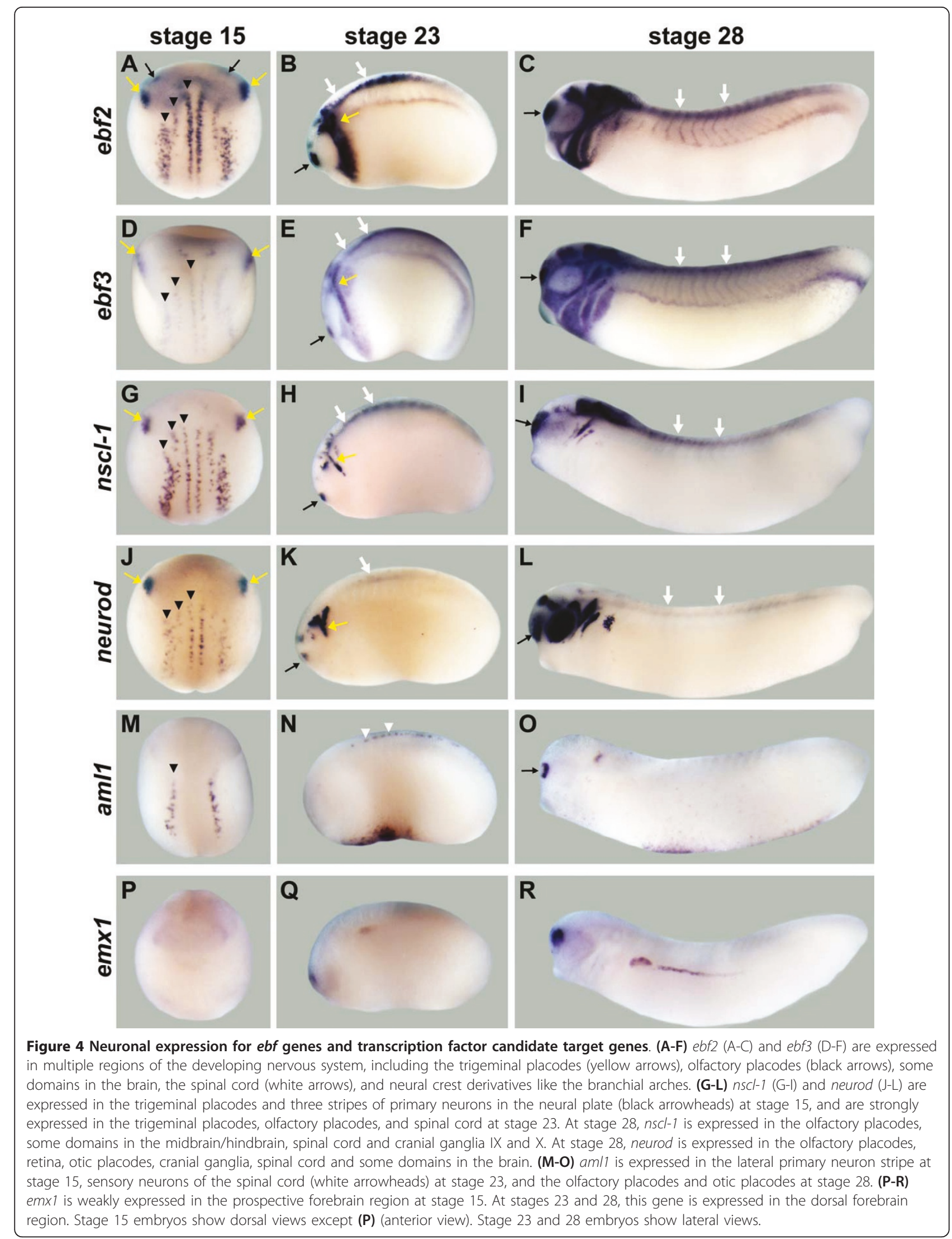



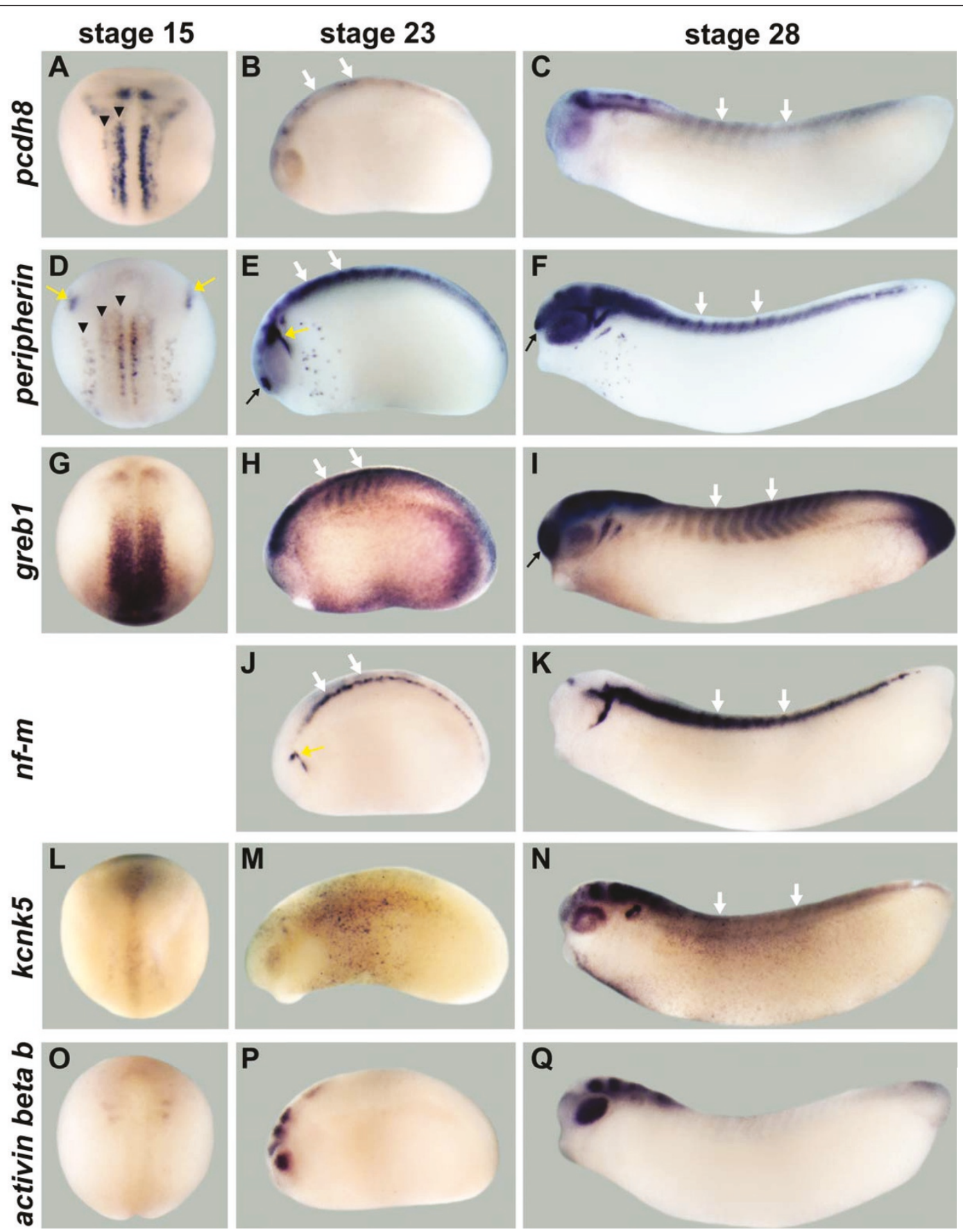

Figure $\mathbf{5}$ Neuronal expression for non-transcription factor candidate target genes. (A-C) pcdh8 is expressed in medial and intermediate stripes (arrowheads) of primary neurons, in one posterior stripe between the two stripes of primary neurons, and in the anterior domain of the neural plate at stage 15, and in the spinal cord (white arrows) and some domains in the brain at stages 23 and 28. (D-F) peripherin is expressed in the trigeminal placodes (yellow arrows) and three stripes of primary neurons (arrowheads) at stage 15, and in the trigeminal placodes, olfactory placodes (black arrow), spinal cord, retina and many domains in the brain at stages 23 and 28. (G-I) greb1 is expressed as a band in the prospective midbrain/hindbrain region at stage 15 , and in the midbrain/hindbrain region and spinal cord at stage 23 , and in the olfactory placodes, spinal cord, and many domains in the brain at stage 28. $(\mathbf{J}, \mathbf{K}) n f-m$ is not expressed at stage 15 , but at stages 23 and 28 it is expressed in the trigeminal placodes and spinal cord. (L-N) $k$ cnk5 is weakly expressed from anterior to posterior along the dorsal midline, with stronger expression in the anterior end of the neural fold at stage 15. It is expressed in retina, otic placode, and several domains in the brain at stages 23 and 28 , and in spinal cord at stage 28. (O-Q) activin beta $b$ is expressed in two bands in the prospective midbrain/hindbrain region and diffusely throughout the anterior neural plate at stage 15, and it is expressed in the retina and some brain domains at stages 23 and 28 . Stage 15 embryos show dorsal views, and stages 23 and 28 embryos show lateral views. 
and $k c n k 5$ have not previously been described during Xenopus neuronal development.

\section{Identification of direct candidate targets for EBF3 in animal caps by RT-QPCR}

To better understand the transcriptional interaction between EBF3 and its candidate target genes, we sought to identify which genes are direct transcriptional candidate targets and which are indirect transcriptional candidate targets. We used an approach similar to the microarray analysis, with DEX treatment of animal caps to drive activation of hGR-XEBF3, but we added CHX to block protein synthesis, so that only direct EBF3 candidate targets should be transcribed. Animal caps were collected at stage 9 after injection of hGR-XEBF3, and divided into four groups: untreated control (-C-D), DEX alone $(-\mathrm{C}+\mathrm{D}), \mathrm{CHX}$ alone $(+\mathrm{C}-\mathrm{D})$, and both $\mathrm{CHX}$ and DEX $(+\mathrm{C}+\mathrm{D})$. All animal caps were collected after a 3.5hour incubation. CHX treatment lasted the entire 3.5 hours, while DEX treatment started after a 30-minute delay to allow time for CHX to take effect. The expression level of each candidate target was examined by RTQPCR (Table 1 and Figure 6; Additional file 6). We normalized the expression level of candidate target genes with that of histone h4, and for Figure 6 and Additional file 6 we set the normalized expression level in the condition of $-\mathrm{C}+\mathrm{D}$ to $100 \%$ (see Materials and methods).

After treatment with both CHX and DEX, candidate targets that had expression levels of less than $10 \%$ of the level in animal caps treated with DEX alone (or candidates that had expression levels similar to untreated controls, even if that was greater than $10 \%$ of the DEX alone condition) were considered to be indirect candidate targets. These indirect targets are pcdh $8, k c n k 5$, activin beta $b$, neurod and greb1 (Figure 6B; Additional file 6D-G). Candidate target genes with expression levels of greater than $50 \%$ of the levels in animal caps treated with DEX alone are candidate targets for which the majority of their expression is directly controlled by EBF3. These include peripherin, $e m x 1$ and $n f-m$ (Figure $6 \mathrm{~A}$; Additional file 6AB). Finally, there are genes with expression levels between 10 and $50 \%$ of the level in animal caps treated with DEX alone. These genes, including aml1 and $n s c l-1$, likely have some expression that is under direct regulation by EBF3 (Figure 6C; Additional file $6 \mathrm{C}$ ), suggesting that their expression is controlled not only by EBF3 directly but also through other targets of EBF3.

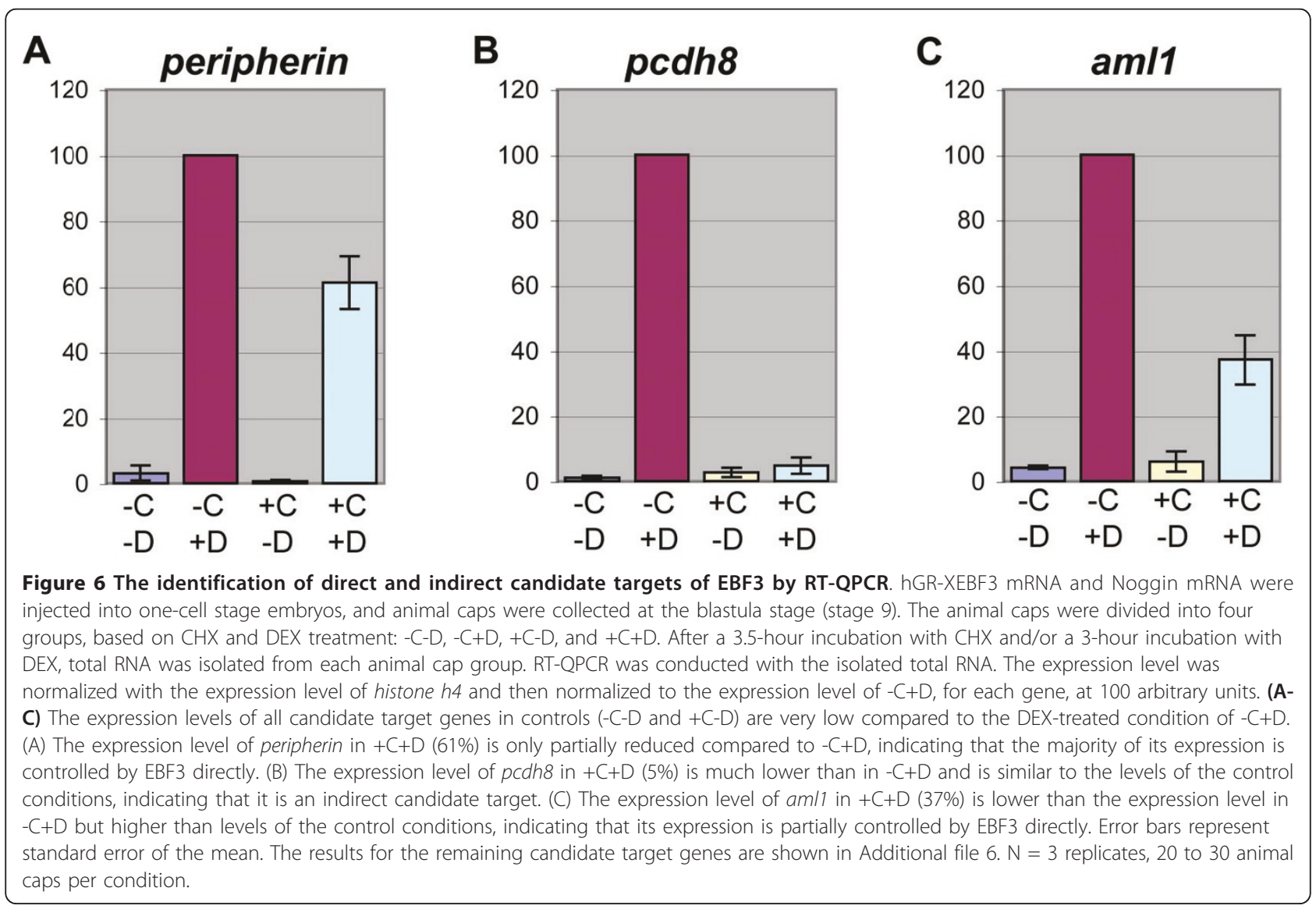




\section{Discussion}

To better understand the range of activities that are driven by EBF transcription factors during neural development, we used a systematic approach to identify candidate target genes of EBF activity in Xenopus. In this study, we emphasize candidate targets that were highly upregulated by EBF activity by microarray analysis and with potential functions in neuronal development. Our microarray screen for targets of EBF transcriptional activity revealed many genes that were previously not known to be targets of EBF activity. Ten of the genes showed upregulation after EBF overexpression, and downregulation after EBF knockdown in neurula or tailbud stage embryos, demonstrating their in vivo dependence on EBF activity. In addition, all ten of these genes partially overlap in their expression with $e b f$ genes, consistent with regulation by EBF proteins during neural development. Since some of these genes are direct targets with partial dependency on EBF activity, others are indirect candidate targets, and most have only partially overlapping expression with ebf genes, it is clear that EBF proteins are part of a more complex transcriptional regulatory network involved in driving their expression. The candidate target genes we identified by microarray analysis, but did not characterize further, also have the potential to reveal involvement of EBF proteins in additional activities, and this list of genes should aid future research into EBF functions.

Several previous studies, including EBF gain- and lossof-function studies in Drosophila, C. elegans, ebf mutant mice, chicks, Xenopus, and in cell lines, have revealed a number of neuronal genes that are regulated by EBF transcriptional activity $[2,7,8,15-17,19,53-56]$. With the exception of $n f-m$, the list of candidate EBF target genes that we selected for analysis does not include these previously described EBF-regulated genes. However, among the additional genes from the microarray that are upregulated by EBF activity we found $l h x 9$ and $l m o 4$, which are homologous to apterous, a known target of Collier in Drosophila [17]. It is likely that we did not recognize the presence of other known EBF target genes in our array results due to the incomplete annotation of the Xenopus microarray. Another explanation could be that expression of these targets is driven by EBF in the more differentiated environments of each independent experiment, but not in the relatively naïve environment of Xenopus animal caps. Future improvements in Xenopus annotation should make it possible to help distinguish between these two explanations.

We find in our Xenopus EBF screens comparable numbers of strongly downregulated genes and strongly upregulated genes. This parallels the important roles shown for EBF proteins functioning as transcriptional repressors to help determine cell fate in cell types such as B cells in mice $[37,57,58]$ and ASI chemosensory neurons in C. elegans [55]. As part of a future study, it will be interesting to see the extent to which our candidate downregulated genes are related to cell fate.

EBF proteins are involved in the development of multiple lineages, including B cells and adipocytes. Interestingly, in our array analysis we found genes with known roles in non-neuronal tissue types like myod, which regulates muscle development, or $1 m o 2$ and hex, which are involved in leukocyte development. These genes were upregulated even after animal caps were neuralized with Noggin. Thus, in the relatively naive environment of animal cap ectoderm it may be permissive for EBF target genes from multiple lineages to be expressed. EBF proteins have been proposed to function as pioneer factors for $B$ cell genes in hematopoietic lineages [37]. Therefore, EBF factors may alter chromatin to permit genes involved in lineage specification and differentiation to be expressed. There have been screens performed to identify targets of EBF proteins in non-neuronal cell types such as B cells and adipocytes $[37,59,60]$. A detailed comparison of our array results with these studies is difficult since limited annotation of the Хenopus arrays precludes systematic cross-species comparisons.

\section{EBF regulation of multiple transcription factor genes suggests involvement in extensive transcriptional networks for neuronal development}

Our finding that several transcription factors are among the strongest candidate targets of EBF activity expands the potential means by which EBF activity could exert its many effects on neuronal development, and also suggests some interesting new potential functions. The bHLH transcription factor NSCL-1 can drive expression of the proneural bHLH transcription factor NGNR-1, which is important for neuronal cell commitment in Xenopus embryos $[40,61]$. In chick and mouse, NSCL-1 can promote neuronal cell differentiation, and migration of cellular populations, including GnRH-1 neurons [62-64]. Interestingly, $E b f 2$ knockout mice show a migration defect of GnRH-1 neurons [21]. We find that the expression of $n s c l-1$ is partially under the direct control of EBF activity, and that the expression patterns of $n s c l-1$ and $e b f$ genes strongly overlap. This suggests that EBF activity may act through NSCL-1 to regulate neuronal cell commitment, differentiation or migration.

The well-known functions of the proneural bHLH transcription factor NeuroD in multiple species show that it is involved primarily in differentiation, but also acts to regulate cell fate, cell migration and cell survival [33,65-68]. This study and previous studies show that neurod expression is very similar to that of $e b f$ genes $[7,8,33]$. Previous studies showed that neurod is both 
downstream of EBF2 and upstream of ebf2 and ebf3 in Xenopus embryos $[7,8,28,65]$. Our present data suggest that neurod is also an indirect candidate target of EBF3. Together, these results support and expand the concept of multiple transcriptional interactions between EBF proteins and NeuroD $[7,8,28,65]$.

AML1, a runt related transcription factor, is known to be expressed in neurons, including cortical progenitors, olfactory receptor progenitors and neurons in the dorsal root ganglia and to be involved in differentiation and cell type specification of several types of sensory and motor neurons, including neurons in the dorsal root ganglia [42,69-71]. Interestingly, AML1 is known to cooperate with EBF proteins in B cell development [72]. We find that aml1 is partially under the direct control of EBF activity, and that the expression patterns of aml1 and ebf genes overlap strongly in the nervous system. Thus, AML1 and EBF proteins may also act cooperatively in promoting neuronal differentiation.

In multiple species, the homeobox transcription factor Emx1 is strongly expressed in the developing forebrain, and the EMX1 protein is present in the axons of the olfactory neurons $[44,73,74]$. Compared to $E m \times 2$ knockout mice, $E m \times 1$ knockout mice show only minor defects in brain development [75-77]. However, $E m \times 1$ and $E m \times 2$ double mutant mice show more severe defects than $E m x 2$ knockout mice, including defects of neuronal differentiation and thalamocortical pathfinding [78], similar to those found in $E b f 1$ knockout mice [16]. Since we find $e m x 1$ to be a strong, direct candidate target of EBF proteins, and $e m x 1$ and $e b f$ genes are both strongly expressed in the forebrain, EBF proteins may control cell differentiation and axon growth in part by driving expression of $e m \times 1$.

\section{EBF proteins drive expression of candidate targets involved in multiple aspects of neuronal differentiation}

The candidate targets that are not transcription factors illuminate some of the ways that EBF activity could help regulate late steps of neuronal differentiation and neuronal function. Peripherin and NF-M are important components of neuronal intermediate filaments, which help to form the cytoskeleton in the cell body and neurites of neurons [79-82]. We find that the majority of expression of peripherin and $n f-m$ is controlled directly by EBF3, and that their expression strongly overlaps with that of $e b f$ genes. These discoveries correlate with previous evidence showing axonal pathfinding defects of thalamocortical and olfactory receptor neurons in $E b f$ null mice, pathfinding defects of motor neurons in C. elegans UNC3 mutants, and problems with dendritic arborization in Drosophila Collier mutants $[11,16,19,20,53,54,83]$. These correlations both support a role for EBF proteins in axon growth or stability and provide a potential additional route for exploration of how EBF proteins can affect this important process.

PCDH8 is a transmembrane calcium-dependant adhesion molecule. The rat homolog Arcadlin affects the number of dendritic spines in cultured hippocampal neurons [84] and is required for activity-induced long-term potentiation [85]. We find that EBF proteins positively regulate the expression of a gene that is likely the Xenopus pcdh 8 homolog (based on sequence similarity and similar range of gene expression with mouse Pcdh8 in midbrain, hindbrain and spinal cord [86]). We show that $p c d h 8$ is an indirect candidate target of EBF activity, and that $p c d h 8$ and $e b f$ expression patterns overlap in the brain and spinal cord, suggesting that EBF proteins may be involved in synaptic plasticity by controlling the expression of $p c d h 8$, which would be a new function for EBF proteins in the nervous system.

KCNK5 is a $\mathrm{K}+$ channel that is sensitive to extracellular $\mathrm{pH}$, and in rat kidney cells it functions to stabilize bicarbonate transport and control cell volume $[49,87,88]$. It appears to be involved in maintaining the membrane potential of chemoreceptor cells in mouse brainstem [89]. We find that Xenopus kcnk5 is indirectly upregulated by EBF activity. In addition, we find overlap between $e b f$ and $k c n k 5$ gene expression in the midbrain and hindbrain at the tailbud stage. Regulation of this gene represents a previously unknown function for EBF transcriptional activity.

Activin beta B forms homodimers, or heterodimers with Activin beta A. Activins are ligands of the TGF-beta superfamily, which are involved in differentiation in tissues from many systems, including the reproductive system [90-93]. Activin beta $B$ is expressed in the developing brain and retina $([50,94,95]$ and our data), but its function in neuronal development is not yet clear. Our study shows that the activin beta $b$ gene is likely an indirect candidate target of EBF proteins, and that its expression precedes that of $e b f$ genes in midbrain, hindbrain and retina. These results suggest that EBF activity may maintain the expression of activin beta $b$ instead of initiating its expression.

The protein GREB1 is thought to be involved in the estrogen-induced growth of breast cancer cells $[96,97]$, but its function is not known, and its expression pattern in animal development has not been previously described. We find that greb1 is expressed in several tissues, including neurons and muscle cells, during Xenopus development. Overlapping expression with ebf genes is limited to the spinal cord and a few brain regions at tailbud stages, and we find that the expression of greb1 is controlled by EBF proteins indirectly. Our findings demonstrate a potential relationship between these genes and a possible role for GREB1 in neuronal development. 


\section{Candidate targets that overlap most with ebf genes tend to be direct targets}

Interestingly, the candidate targets having direct dependency on EBF3 for their expression, based on our CHX experiments (Figure 6; Additional file 6), tended to have the most overlap with ebf genes in their WM-ISH expression patterns (Figures 4 and 5). These included the genes that code for axonal structural proteins (peripherin and $n f-m)$ and two that code for transcription factors (aml1 and nscl-1). In contrast, the genes that appear to be indirect candidate targets tended to be those that have the least overlap with $e b f$ genes in their expression patterns. These included pcdh8, kcnk5, activin beta $b$, and greb1. An exception to this rule was neurod, which has extensive overlap with ebf genes, but is an indirect target. This could reflect the fact that neurod is also upstream of $e b f$ genes $[7,8,28,65]$. These results strengthen the conclusion that in vivo expression of the candidate target genes determined to have direct dependency on EBF3 transcriptional activity is likely to be heavily dependent on EBF activity.

\section{EBF proteins function in cell commitment and} differentiation in the development of multiple lineages EBF proteins have been implicated in the specification, commitment, and differentiation of specific cell types by regulating the expression of both genes in transcriptional regulatory networks as well as genes involved in the functional activities of a cell type, consistent with what we found in our analysis. For example, EBF1 is known to participate in B cell specification, commitment, and differentiation by inducing the expression of transcription factors like E2A (Tcf3) and Pax5, and nontranscription factors like CD79a (mb-1) and VpreB $[37,60,98,99]$. EBF proteins similarly participate in adipocyte differentiation, by inducing the expression of both types of genes [59,100,101].

In $\mathrm{B}$ cells EBF1 acts cooperatively with other transcription factors, including AML1 (RUNX1), E2A, Pax5, and Foxo1, by driving expression of overlapping sets of target genes ([102] and reviewed in [36,103-105]). Interestingly, these transcription factors are themselves targets of EBF1 in B cells. Similar mechanisms are found during neuronal subtype development in the Drosophila ventral nerve cord [17]. The fact that AML1 is also one of our candidate targets, and that most of our transcription factor candidate targets have extensive and early co-expression with ebf 2 and ebf3, suggests that EBF proteins may act cooperatively with their transcription factor targets for the expression of some genes in Xenopus neuronal development. Cooperative regulation of gene expression could be part of positive feedback mechanisms that solidify cell commitment choices and differentiated states.
EBF2 and EBF3 appear to share most candidate targets during early Xenopus development

In the developing mouse nervous system, there is evidence for areas of overlap in the functions of different members of the EBF family. For example, Ebf2 and Ebf 3 knockout mice have similar phenotypes for olfactory axon growth [20], and Ebf1 null mice do not show severe defects in the brain regions expressing multiple EBF family members concomitantly $[1,2,5,16,98]$. However, there is also evidence for distinct functions of different members, including the fact that Ebf1 is the only member expressed in the embryonic striatum and Ebf1 null mice show defective neuronal cell differentiation in that region $[1,16]$. In addition, Ebf2 null mice show defective migration of GnRH-1 neurons even though Ebf1 is also expressed in those neurons [21,106]. In Xenopus, the previously known functions of EBF2 and EBF3 are very similar during early development $[7,8]$. They are both important for neuronal differentiation, including control of the expression of the neuronal specific markers N-tubulin, N-CAM, and NF-M. Supporting the similarity of the roles of these two genes, we find that the ten candidate targets of EBF3 that were upregulated by hGR-XEBF3 in Xenopus animal caps and in vivo could also be upregulated by hGR-XEBF2 in vivo. Although there is interesting evidence for some differences in expression patterns and functions of EBF2 and EBF3 $[7,8]$, our results support the idea that EBF2 and EBF3 have largely redundant functions at the transcriptional level.

\section{Conclusions}

We have found multiple EBF candidate targets using a systematic approach in Xenopus embryos. The expression patterns of direct candidate targets of EBF3 have strong overlap with ebf gene expression, while candidate targets having largely indirect dependency on EBF3 are expressed in less overlapping patterns, suggesting more complex modes of regulation. The novel candidate target genes suggest new potential routes for EBF transcription factors to carry out their previously known functions of neuronal cell commitment, differentiation, neurite formation and migration, and also suggest some new potential functions of EBF activity.

\section{Additional material}

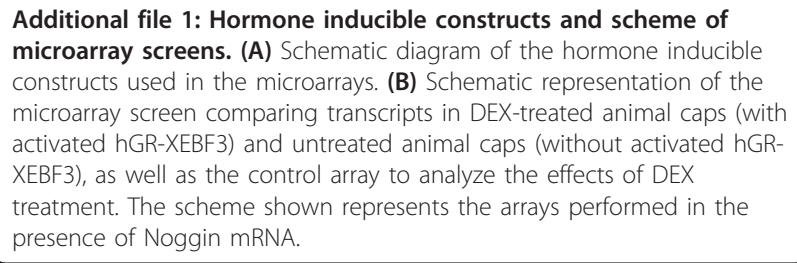




\section{Additional file 2: Primer sequences used for RT-QPCR. \\ Additional file 3: Microarray results table showing genes up- or downregulated more than two-fold by EBF3 activity in the presence of Noggin.}

Additional file 4: Microarray results table showing genes up- or downregulated more than two-fold by EBF3 activity in the absence of Noggin.

Additional file 5: Expression of peripherin in embryos treated with EBF2 MO and EBF3 MO can be rescued by co-injection of hGRXEBF2. One cell of two-cell stage embryos was injected with EBF2 MO, EBF3 MO and mRNA encoding hGR-XEBF2, followed by DEX treatment (or no treatment in controls) from the late gastrula stage (stage 11.5) to the neurula stage (stage 15/16). $\beta$-Galactosidase ( $\beta$-gal) mRNA was coinjected as a marker of the injected side. In both panels the right side is the injected side (brackets). In control embryos (without DEX treatment) peripherin expression was downregulated either strongly (3/7, shown in (A)) or weakly (4/7, not shown) compared to the uninjected side due to the $\mathrm{MO}$ effect. In the majority of DEX-treated embryos peripherin expression was either rescued (16/34, shown in (B)), or only weakly downregulated (17/34, not shown). Both panels show dorsal views.

Additional file 6: Additional identification of direct and indirect candidate targets of EBF3 by RT-QPCR. Expression levels for the remaining candidate target genes tested by RT-QPCR after CHX and DEX treatment (those not shown in Figure 6). (A,B) The expression levels of emx1 (88\%) and $n f-m(56 \%)$ in $+C+D$ are slightly lower than in $-C+D$, indicating that the majority of their expression is controlled by EBF3 directly. (C) The expression level of nscl- 1 (46\%) in $+C+D$ is lower than in $-C+D$ but higher than that in the two controls, indicating that its expression is under partial direct control of EBF3. (D-G) The expression levels of kcnk5 (20\%), activin beta b (10\%), neurod (8\%) and greb1 (1\%) in $+C+D$ are similar to control levels (D) or much lower (less than 10\%) than in $-C+D(E-G)$. $N=20$ to 30 animal caps per condition.

\section{Abbreviations \\ bHLH: basic helix-loop-helix; CHX: cycloheximide; COE: Collier/Olf/Ebf; DEX: dexamethasone; EBF: early B cell factor; GEO: Gene Expression Omnibus; GnRH: gonadotropin releasing hormone; hGR: human glucocorticoid receptor; MO: morpholino; nf-m: neurofilament-m; O/E: Olf/Ebf; RT-PCR: reverse transcriptase PCR; RT-QPCR: real-time quantitative PCR; TGF: transforming growth factor; WM-ISH: whole mount in situ hybridization.}

\section{Acknowledgements}

We thank Brett Milash for assistance with the microarray data analysis. We thank Kathryn Moore, Jianmin Zhang, and Eric Green for critical comments on the manuscript. We thank Richard Harland for the pCS2+Noggin construct, Ombretta Pozzoli for the pCS2+hGR-MT-Xebf3 construct, and David Hutcheson for the pCS2+hGR-MT construct. This work was funded by $\mathrm{NIH}$ grant EY012274 to MLV.

\section{Authors' contributions}

YSG participated in the design of these experiments, performed the experiments, analyzed most of the data, and wrote the manuscript. MLV guided the design of the experiments and aided the writing and data analysis. Both authors approved the final manuscript.

\section{Competing interests}

The authors declare that they have no competing interests.

Received: 23 September 2010 Accepted: 30 April 2011

Published: 30 April 2011

\section{References}

1. Garel S, Marin F, Mattei MG, Vesque C, Vincent A, Charnay P: Family of Ebf/ Olf-1-related genes potentially involved in neuronal differentiation and regional specification in the central nervous system. Dev Dyn 1997, 210:191-205.
2. Wang SS, Tsai RY, Reed RR: The characterization of the Olf-1/EBF-like HLH transcription factor family: implications in olfactory gene regulation and neuronal development. J Neurosci 1997, 17:4149-4158.

3. Kudrycki K, Stein-Izsak C, Behn C, Grillo M, Akeson R, Margolis FL: Olf-1binding site: characterization of an olfactory neuron-specific promoter motif. Mol Cell Biol 1993, 13:3002-3014.

4. Hagman J, Belanger C, Travis A, Turck CW, Grosschedl R: Cloning and functional characterization of early B-cell factor, a regulator of lymphocyte-specific gene expression. Genes Dev 1993, 7:760-773.

5. Malgaretti N, Pozzoli O, Bosetti A, Corradi A, Ciarmatori S, Panigada M, Bianchi ME, Martinez S, Consalez GG: Mmot1, a new helix-loop-helix transcription factor gene displaying a sharp expression boundary in the embryonic mouse brain. J Biol Chem 1997, 272:17632-17639.

6. Wang SS, Betz AG, Reed RR: Cloning of a novel Olf-1/EBF-like gene, O/E-4, by degenerate oligo-based direct selection. Mol Cell Neurosci 2002, 20:404-414.

7. Dubois L, Bally-Cuif L, Crozatier M, Moreau J, Paquereau L, Vincent A: XCoe2, a transcription factor of the Col/Olf-1/EBF family involved in the specification of primary neurons in Xenopus. Curr Biol 1998, 8:199-209.

8. Pozzoli O, Bosetti A, Croci L, Consalez GG, Vetter ML: Xebf3 is a regulator of neuronal differentiation during primary neurogenesis in Xenopus. Dev Biol 2001, 233:495-512.

9. Bally-Cuif $L$, Dubois L, Vincent A: Molecular cloning of Zcoe2, the zebrafish homolog of Xenopus Xcoe2 and mouse EBF-2, and its expression during primary neurogenesis. Mech Dev 1998, 77:85-90.

10. Crozatier M, Valle D, Dubois L, Ibnsouda S, Vincent A: Collier, a novel regulator of Drosophila head development, is expressed in a single mitotic domain. Curr Biol 1996, 6:707-718.

11. Prasad BC, Ye B, Zackhary R, Schrader K, Seydoux G, Reed RR: unc-3, a gene required for axonal guidance in Caenorhabditis elegans, encodes a member of the O/E family of transcription factors. Development 1998, 125:1561-1568.

12. Hagman J, Gutch MJ, Lin H, Grosschedl R: EBF contains a novel zinc coordination motif and multiple dimerization and transcriptional activation domains. EMBO J 1995, 14:2907-2916.

13. Dubois $L$, Vincent $A$ : The COE - Collier/Olf1/EBF - transcription factors: structural conservation and diversity of developmental functions. Mech Dev 2001, 108:3-12.

14. Liberg D, Sigvardsson M, Akerblad P: The EBF/Olf/Collier family of transcription factors: regulators of differentiation in cells originating from all three embryonal germ layers. Mol Cell Biol 2002, 22:8389-8397.

15. Garcia-Dominguez M, Poquet C, Garel S, Charnay P: Ebf gene function is required for coupling neuronal differentiation and cell cycle exit. Development 2003, 130:6013-6025.

16. Garel S, Marin F, Grosschedl R, Charnay P: Ebf1 controls early cell differentiation in the embryonic striatum. Development 1999, 126:5285-5294.

17. Baumgardt M, Miguel-Aliaga I, Karlsson D, Ekman H, Thor S: Specification of neuronal identities by feedforward combinatorial coding. PLOS Biol 2007, 5:e37.

18. Prasad B, Karakuzu O, Reed RR, Cameron S: unc-3-dependent repression of specific motor neuron fates in Caenorhabditis elegans. Dev Biol 2008, 323:207-215.

19. Garel S, Yun K, Grosschedl R, Rubenstein JL: The early topography of thalamocortical projections is shifted in Ebf1 and Dlx1/2 mutant mice. Development 2002, 129:5621-5634.

20. Wang SS, Lewcock JW, Feinstein P, Mombaerts P, Reed RR: Genetic disruptions of O/E2 and O/E3 genes reveal involvement in olfactory receptor neuron projection. Development 2004, 131:1377-1388.

21. Corradi A, Croci L, Broccoli V, Zecchini S, Previtali S, Wurst W, Amadio S, Maggi R, Quattrini A, Consalez GG: Hypogonadotropic hypogonadism and peripheral neuropathy in Ebf2-null mice. Development 2003, 130:401-410.

22. Croci L, Chung SH, Masserdotti G, Gianola S, Bizzoca A, Gennarini G, Corradi A, Rossi F, Hawkes R, Consalez GG: A key role for the HLH transcription factor EBF2COE2, O/E-3 in Purkinje neuron migration and cerebellar cortical topography. Development 2006, 133:2719-2729.

23. Garel S, Garcia-Dominguez M, Charnay P: Control of the migratory pathway of facial branchiomotor neurones. Development 2000, 127:5297-5307.

24. Davis JA, Reed RR: Role of Olf- 1 and Pax- 6 transcription factors in neurodevelopment. J Neurosci 1996, 16:5082-5094. 
25. Hutcheson DA, Vetter ML: The bHLH factors Xath5 and XNeuroD can upregulate the expression of $\mathrm{XBrn3 \textrm {d }}$, a POU-homeodomain transcription factor. Dev Biol 2001, 232:327-338.

26. Kolm PJ, Sive HL: Efficient hormone-inducible protein function in Xenopus laevis. Dev Biol 1995, 171:267-272.

27. Lamb TM, Knecht AK, Smith WC, Stachel SE, Economides AN, Stahl N, Yancopolous GD, Harland RM: Neural induction by the secreted polypeptide noggin. Science 1993, 262:713-718.

28. Logan MA, Steele MR, Van Raay TJ, Vetter ML: Identification of shared transcriptional targets for the proneural bHLH factors Xath5 and XNeuroD. Dev Biol 2005, 285:570-583.

29. Chitnis A, Henrique D, Lewis J, Ish-Horowicz D, Kintner C: Primary neurogenesis in Xenopus embryos regulated by a homologue of the Drosophila neurogenic gene Delta. Nature 1995, 375:761-766.

30. Nieuwkoop PD, Faber J: Normal Table of Xenopus laevis (Daudin): a Systematical and Chronological Survey of the Development from the Fertilized Egg Till the End of Metamorphosis New York: Garland Publishing; 1994.

31. Turner DL, Weintraub H: Expression of achaete-scute homolog 3 in Xenopus embryos converts ectodermal cells to a neural fate. Genes Dev 1994, 8:1434-1447.

32. Mizuseki K, Kishi M, Matsui M, Nakanishi S, Sasai Y: Xenopus Zic-related-1 and Sox-2, two factors induced by chordin, have distinct activities in the initiation of neural induction. Development 1998, 125:579-587.

33. Lee JE, Hollenberg SM, Snider L, Turner DL, Lipnick N, Weintraub H: Conversion of Xenopus ectoderm into neurons by NeuroD, a basic helixloop-helix protein. Science 1995, 268:836-844.

34. Kanekar S, Perron M, Dorsky R, Harris WA, Jan LY, Jan YN, Vetter ML: Xath5 participates in a network of bHLH genes in the developing Xenopus retina. Neuron 1997, 19:981-994.

35. Harland RM: In situ hybridization: an improved whole-mount method for Xenopus embryos. Methods Cell Biol 1991, 36:685-695.

36. Lukin K, Fields S, Hartley J, Hagman J: Early B cell factor: regulator of B lineage specification and commitment. Semin Immunol 2008, 20:221-227.

37. Treiber T, Mandel EM, Pott S, Gyory I, Firner S, Liu ET, Grosschedl R: Early B cell factor 1 regulates $B$ cell gene networks by activation, repression, and transcription- independent poising of chromatin. Immunity 2010, 32:714-725.

38. van der Wees J, Matharu PJ, de Roos K, Destree OH, Godsave SF, Durston AJ, Sweeney GE: Developmental expression and differential regulation by retinoic acid of Xenopus COUP-TF-A and COUP-TF-B. Mech Dev 1996, 54:173-184.

39. Dolle P, Izpisua-Belmonte JC, Falkenstein H, Renucci A, Duboule D: Coordinate expression of the murine Hox-5 complex homoeoboxcontaining genes during limb pattern formation. Nature 1989, 342:767-772.

40. Bao J, Talmage DA, Role LW, Gautier J: Regulation of neurogenesis by interactions between HEN1 and neuronal LMO proteins. Development 2000, 127:425-435

41. Hemmati-Brivanlou A, de la Torre JR, Holt C, Harland RM: Cephalic expression and molecular characterization of Xenopus En-2. Development 1991, 111:715-724

42. Park BY, Saint-Jeannet JP: Expression analysis of Runx3 and other Runx family members during Xenopus development. Gene Expr Patterns 2010, 10:159-166.

43. Tracey WD Jr, Pepling ME, Horb ME, Thomsen GH, Gergen JP: A Xenopus homologue of aml-1 reveals unexpected patterning mechanisms leading to the formation of embryonic blood. Development 1998, 125:1371-1380.

44. Pannese M, Lupo G, Kablar B, Boncinelli E, Barsacchi G, Vignali R: The Xenopus Emx genes identify presumptive dorsal telencephalon and are induced by head organizer signals. Mech Dev 1998, 73:73-83.

45. Strehl S, Glatt K, Liu QM, Glatt H, Lalande M: Characterization of two novel protocadherins ( $\mathrm{PCDH} 8$ and $\mathrm{PCDH}$ ) localized on human chromosome 13 and mouse chromosome 14. Genomics 1998, 53:81-89.

46. Wolda SL, Moody CJ, Moon RT: Overlapping expression of Xwnt-3A and Xwnt-1 in neural tissue of Xenopus laevis embryos. Dev Biol 1993, 155:46-57.

47. Sharpe CR: Developmental expression of a neurofilament-M and two vimentin-like genes in Xenopus laevis. Development 1988, 103:269-277.

48. Sharpe CR, Pluck A, Gurdon JB: XIF3, a Xenopus peripherin gene, requires an inductive signal for enhanced expression in anterior neural tissue. Development 1989, 107:701-714.
49. Reyes R, Duprat F, Lesage F, Fink M, Salinas M, Farman N, Lazdunski M: Cloning and expression of a novel $\mathrm{pH}$-sensitive two pore domain $\mathrm{K}+$ channel from human kidney. J Biol Chem 1998, 273:30863-30869.

50. Dohrmann CE, Hemmati-Brivanlou A, Thomsen GH, Fields A, Woolf TM, Melton DA: Expression of activin mRNA during early development in Xenopus laevis. Dev Biol 1993, 157:474-483.

51. Gervasi C, Stewart CB, Szaro BG: Xenopus laevis peripherin (XIF3) is expressed in radial glia and proliferating neural epithelial cells as well as in neurons. J Comp Neurol 2000, 423:512-531.

52. Gervasi C, Szaro BG: Sequence and expression patterns of two forms of the middle molecular weight neurofilament protein (NF-M) of Xenopus laevis. Brain Res Mol Brain Res 1997, 48:229-242.

53. Crozatier M, Vincent A: Control of multidendritic neuron differentiation in Drosophila: the role of Collier. Dev Biol 2008, 315:232-242.

54. Jinushi-Nakao S, Arvind R, Amikura R, Kinameri E, Liu AW, Moore AW: Knot/ Collier and cut control different aspects of dendrite cytoskeleton and synergize to define final arbor shape. Neuron 2007, 56:963-978.

55. Kim K, Colosimo ME, Yeung H, Sengupta P: The UNC-3 Olf/EBF protein represses alternate neuronal programs to specify chemosensory neuron identity. Dev Biol 2005, 286:136-148.

56. Persson P, Manetopoulos C, Lagergren A, Nygren J, Gisler R, Axelson H, Sigvardsson M: Olf/EBF proteins are expressed in neuroblastoma cells: potential regulators of the Chromogranin A and SCG10 promoters. Int J Cancer 2004, 110:22-30.

57. Pongubala JM, Northrup DL, Lancki DW, Medina KL, Treiber T, Bertolino E, Thomas M, Grosschedl R, Allman D, Singh H: Transcription factor EBF restricts alternative lineage options and promotes $B$ cell fate commitment independently of Pax5. Nat Immunol 2008, 9:203-215.

58. Thal MA, Carvalho TL, He T, Kim HG, Gao H, Hagman J, Klug CA: Ebf1mediated down-regulation of Id2 and Id 3 is essential for specification of the B cell lineage. Proc Natl Acad Sci USA 2009, 106:552-557.

59. Akerblad P, Mansson R, Lagergren A, Westerlund S, Basta B, Lind U, Thelin A, Gisler R, Liberg D, Nelander S, Bamberg K, Sigvardsson M: Gene expression analysis suggests that EBF-1 and PPARgamma2 induce adipogenesis of $\mathrm{NIH}-3 \mathrm{~T} 3$ cells with similar efficiency and kinetics. Physiol Genomics 2005, 23:206-216

60. Mansson R, Tsapogas P, Akerlund M, Lagergren A, Gisler R, Sigvardsson M: Pearson correlation analysis of microarray data allows for the identification of genetic targets for early B-cell factor. J Biol Chem 2004, 279:17905-17913.

61. Ma Q, Kintner C, Anderson DJ: Identification of neurogenin, a vertebrate neuronal determination gene. Cell 1996, 87:43-52.

62. Kruger M, Ruschke K, Braun T: NSCL-1 and NSCL-2 synergistically determine the fate of $\mathrm{GnRH}-1$ neurons and control necdin gene expression. EMBO J 2004, 23:4353-4364.

63. Schmid T, Kruger M, Braun T: NSCL-1 and -2 control the formation of precerebellar nuclei by orchestrating the migration of neuronal precursor cells. J Neurochem 2007, 102:2061-2072.

64. Xie W, Yan RT, Ma W, Wang SZ: Enhanced retinal ganglion cell differentiation by ath5 and NSCL1 coexpression. Invest Ophthalmol Vis Sci 2004, 45:2922-2928.

65. Seo S, Lim JW, Yellajoshyula D, Chang LW, Kroll KL: Neurogenin and NeuroD direct transcriptional targets and their regulatory enhancers. EMBO J 2007, 26:5093-5108.

66. Liu M, Pleasure SJ, Collins AE, Noebels JL, Naya FJ, Tsai MJ, Lowenstein DH: Loss of BETA2/NeuroD leads to malformation of the dentate gyrus and epilepsy. Proc Natl Acad Sci USA 2000, 97:865-870.

67. Kim WY, Fritzsch B, Serls A, Bakel LA, Huang EJ, Reichardt LF, Barth DS, Lee JE: NeuroD-null mice are deaf due to a severe loss of the inner ear sensory neurons during development. Development 2001, 128:417-426.

68. Ge W, He F, Kim KJ, Blanchi B, Coskun V, Nguyen L, Wu X, Zhao J, Heng Jl, Martinowich K, Tao J, Wu H, Castro D, Sobeih MM, Corfas G, Gleeson JG, Greenberg ME, Guillemot F, Sun YE: Coupling of cell migration with neurogenesis by proneural bHLH factors. Proc Natl Acad Sci USA 2006, 103:1319-1324.

69. Kramer I, Sigrist M, de Nooij JC, Taniuchi I, Jessell TM, Arber S: A role for Runx transcription factor signaling in dorsal root ganglion sensory neuron diversification. Neuron 2006, 49:379-393.

70. Theriault FM, Nuthall HN, Dong Z, Lo R, Barnabe-Heider F, Miller FD, Stifani S: Role for Runx1 in the proliferation and neuronal differentiation 
of selected progenitor cells in the mammalian nervous system. J Neurosci 2005, 25:2050-2061.

71. Theriault FM, Roy P, Stifani S: AML1/Runx1 is important for the development of hindbrain cholinergic branchiovisceral motor neurons and selected cranial sensory neurons. Proc Natl Acad Sci USA 2004, 101:10343-10348.

72. Maier H, Ostraat R, Gao H, Fields S, Shinton SA, Medina KL, Ikawa T, Murre C, Singh H, Hardy RR, Hagman J: Early B cell factor cooperates with Runx 1 and mediates epigenetic changes associated with mb-1 transcription. Nat Immunol 2004, 5:1069-1077.

73. Briata P, Di Blas E, Gulisano M, Mallamaci A, lannone R, Boncinelli E, Corte G: EMX1 homeoprotein is expressed in cell nuclei of the developing cerebral cortex and in the axons of the olfactory sensory neurons. Mech Dev 1996, 57:169-180.

74. Simeone A, Gulisano M, Acampora D, Stornaiuolo A, Rambaldi M, Boncinelli E: Two vertebrate homeobox genes related to the Drosophila empty spiracles gene are expressed in the embryonic cerebral cortex. EMBO J 1992, 11:2541-2550.

75. Pellegrini M, Mansouri A, Simeone A, Boncinelli E, Gruss P: Dentate gyrus formation requires Emx2. Development 1996, 122:3893-3898.

76. Qiu M, Anderson S, Chen S, Meneses JJ, Hevner R, Kuwana E, Pedersen RA, Rubenstein JL: Mutation of the Emx-1 homeobox gene disrupts the corpus callosum. Dev Biol 1996, 178:174-178.

77. Yoshida M, Suda Y, Matsuo I, Miyamoto N, Takeda N, Kuratani S, Aizawa S: Emx1 and Emx2 functions in development of dorsal telencephalon. Development 1997, 124:101-111.

78. Bishop KM, Garel S, Nakagawa Y, Rubenstein JL, O'Leary DD: Emx1 and Emx2 cooperate to regulate cortical size, lamination, neuronal differentiation, development of cortical efferents, and thalamocortical pathfinding. I Comp Neurol 2003, 457:345-360

79. Lin W, Szaro BG: Neurofilaments help maintain normal morphologies and support elongation of neurites in Xenopus laevis cultured embryonic spinal cord neurons. J Neurosci 1995, 15:8331-8344.

80. Helfand BT, Mendez MG, Pugh J, Delsert C, Goldman RD: A role for intermediate filaments in determining and maintaining the shape of nerve cells. Mol Biol Cell 2003, 14:5069-5081.

81. Garcia ML, Lobsiger CS, Shah SB, Deerinck TJ, Crum J, Young D, Ward CM, Crawford TO, Gotow T, Uchiyama Y, Ellisman MH, Calcutt NA,

Cleveland DW: NF-M is an essential target for the myelin-directed "outside-in" signaling cascade that mediates radial axonal growth. J Cell Biol 2003, 163:1011-1020.

82. Smith A, Gervasi C, Szaro BG: Neurofilament content is correlated with branch length in developing collateral branches of Xenopus spinal cord neurons. Neurosci Lett 2006, 403:283-287.

83. Hattori Y, Sugimura K, Uemura T: Selective expression of Knot/Collier, a transcriptional regulator of the EBF/OIf-1 family, endows the Drosophila sensory system with neuronal class-specific elaborated dendritic patterns. Genes Cells 2007, 12:1011-1022.

84. Yasuda S, Tanaka H, Sugiura H, Okamura K, Sakaguchi T, Tran U, Takemiya T, Mizoguchi A, Yagita Y, Sakurai T, De Robertis EM, Yamagata K: Activityinduced protocadherin arcadlin regulates dendritic spine number by triggering $\mathrm{N}$-cadherin endocytosis via TAO2beta and p38 MAP kinases. Neuron 2007, 56:456-471.

85. Yamagata $\mathrm{K}$, Andreasson $\mathrm{Kl}$, Sugiura $\mathrm{H}$, Maru E, Dominique $\mathrm{M}$, Irie $\mathrm{Y}$, Miki $\mathrm{N}$, Hayashi Y, Yoshioka M, Kaneko K, Kato H, Worley PF: Arcadlin is a neural activity-regulated cadherin involved in long term potentiation. $J$ Biol Chem 1999, 274:19473-19479.

86. Makarenkova H, Sugiura H, Yamagata K, Owens G: Alternatively spliced variants of protocadherin 8 exhibit distinct patterns of expression during mouse development. Biochim Biophys Acta 2005, 1681:150-156.

87. Warth $R$, Barriere $H$, Meneton $P$, Bloch $M$, Thomas J, Tauc M, Heitzmann D, Romeo E, Verrey F, Mengual R, Guy N, Bendahhou S, Lesage F, Poujeol P, Barhanin J: Proximal renal tubular acidosis in TASK2 K+ channel-deficient mice reveals a mechanism for stabilizing bicarbonate transport. Proc Natl Acad Sci USA 2004, 101:8215-8220.

88. Barriere H, Belfodil R, Rubera I, Tauc M, Lesage F, Poujeol C, Guy N, Barhanin J, Poujeol P: Role of TASK2 potassium channels regarding volume regulation in primary cultures of mouse proximal tubules. I Gen Physiol 2003, 122:177-190

89. Gestreau C, Heitzmann D, Thomas J, Dubreuil V, Bandulik S, Reichold M, Bendahhou S, Pierson P, Sterner C, Peyronnet-Roux J, Benfriha C,
Tegtmeier I, Ehnes H, Georgieff M, Lesage F, Brunet JF, Goridis C, Warth R, Barhanin J: Task2 potassium channels set central respiratory $\mathrm{CO} 2$ and $\mathrm{O} 2$ sensitivity. Proc Natl Acad Sci USA 2010, 107:2325-2330.

90. Itman C, Mendis S, Barakat B, Loveland KL: All in the family: TGF-beta family action in testis development. Reproduction 2006, 132:233-246.

91. Knight PG, Glister C: TGF-beta superfamily members and ovarian follicle development. Reproduction 2006, 132:191-206.

92. Matzuk MM, Kumar TR, Vassalli A, Bickenbach JR, Roop DR, Jaenisch R, Bradley A: Functional analysis of activins during mammalian development. Nature 1995, 374:354-356.

93. Smith JC, Price BM, Van Nimmen K, Huylebroeck D: Identification of a potent Xenopus mesoderm-inducing factor as a homologue of activin $\mathrm{A}$. Nature 1990, 345:729-731.

94. Roberts VJ, Barth SL, Meunier H, Vale W: Hybridization histochemical and immunohistochemical localization of inhibin/activin subunits and messenger ribonucleic acids in the rat brain. J Comp Neurol 1996, 364:473-493.

95. Belecky-Adams TL, Scheurer D, Adler R: Activin family members in the developing chick retina: expression patterns, protein distribution, and in vitro effects. Dev Biol 1999, 210:107-123.

96. Ghosh MG, Thompson DA, Weigel RJ: PDZK1 and GREB1 are estrogenregulated genes expressed in hormone-responsive breast cancer. Cancer Res 2000, 60:6367-6375.

97. Rae JM, Johnson MD, Scheys JO, Cordero KE, Larios JM, Lippman ME: GREB 1 is a critical regulator of hormone dependent breast cancer growth. Breast Cancer Res Treat 2005, 92:141-149.

98. Lin H, Grosschedl R: Failure of B-cell differentiation in mice lacking the transcription factor EBF. Nature 1995, 376:263-267.

99. Zhang Z, Cotta CV, Stephan RP, deGuzman CG, Klug CA: Enforced expression of $E B F$ in hematopoietic stem cells restricts lymphopoiesis to the $B$ cell lineage. EMBO J 2003, 22:4759-4769.

100. Akerblad P, Lind U, Liberg D, Bamberg K, Sigvardsson M: Early B-cell factor $(\mathrm{O} / \mathrm{E}-1)$ is a promoter of adipogenesis and involved in control of genes important for terminal adipocyte differentiation. Mol Cell Biol 2002, 22:8015-8025.

101. Jimenez MA, Akerblad P, Sigvardsson M, Rosen ED: Critical role for Ebf1 and Ebf2 in the adipogenic transcriptional cascade. Mol Cell Biol 2007, 27:743-757.

102. Lin YC, Jhunjhunwala S, Benner C, Heinz S, Welinder E, Mansson R, Sigvardsson M, Hagman J, Espinoza CA, Dutkowski J, Ideker T, Glass CK, Murre C: A global network of transcription factors, involving E2A, EBF1 and Foxo1, that orchestrates B cell fate. Nat Immunol 2010, 11:635-643.

103. Hagman J, Lukin K: Early B-cell factor 'pioneers' the way for B-cell development. Trends Immunol 2005, 26:455-461.

104. Mandel EM, Grosschedl R: Transcription control of early B cell differentiation. Curr Opin Immunol 2010, 22:161-167.

105. Singh $\mathrm{H}$, Medina KL, Pongubala JM: Contingent gene regulatory networks and B cell fate specification. Proc Natl Acad Sci USA 2005, 102:4949-4953.

106. Wray S: Development of luteinizing hormone releasing hormone neurones. J Neuroendocrinol 2001, 13:3-11.

doi:10.1186/1749-8104-6-19

Cite this article as: Green and Vetter: EBF factors drive expression of multiple classes of target genes governing neuronal development. Neural Development 2011 6:19.

\section{Submit your next manuscript to BioMed Central and take full advantage of:}

- Convenient online submission

- Thorough peer review

- No space constraints or color figure charges

- Immediate publication on acceptance

- Inclusion in PubMed, CAS, Scopus and Google Scholar

- Research which is freely available for redistribution 